\title{
A CONTRIBUTION TO THE BACTERIOLOGY OF MILK.
}

\author{
By ALFRED MAC CONKEY, M.B., B.C., D.P.H., \\ Lister Institute of Preventive Medicine.
}

IN a previous number of this Journal (1905, vol. v. p. 333) reference was made to certain organisms isolated from samples of town milk sold for domestic use. The examination was undertaken for the purpose of ascertaining whether the lactose fermenting organisms present were of the same varieties, and in the same group-proportions as those in cow faeces. This should be, presumably, the case if the statement is correct that it is practically impossible under ordinary conditions to obtain milk uncontaminated with cow-dung. The constant presence of such pollution has been suggested by Park (1901, p. 400) and others. Delépine (1903) considers that "it is even difficult to conceive how slight faecal pollution of cow's milk can entirely be prevented under any circumstance"; and Boekhout and de Vries (1904) are of the same opinion, for they say: "Es wohl kaum Milch geben wird welche nicht mit kleinen Mengen von Kuhfaeces verunreinigt ist." The results given in my previous paper did not lead to a definite conclusion on this point. It was thought, therefore, that it would be of interest to repeat the experiments with country milk as sold for domestic use, and with milk obtained direct from the udder, as thus any change due to bacterial growth during the interval between collection and examination would be minimised or entirely avoided. The technique employed was practically the same as in the previous experiments except that after isolation the organisms were subjected to a greater number of tests. Cultures in gelatin were incubated at room temperature; those in other media were kept at $37^{\circ} \mathrm{C}$. 


\section{Description of samples and of methods used to isolate the organisms.}

Sample 1 was obtained at a farm. It was a poor milk and not clean. Two to three c.c. were put into a tube of bile salt inulin broth and incubated at $37^{\circ} \mathrm{C}$. overnight. Next day surface cultivations were made on bile salt neutral-red lactose agar plates. After 18-24 hours' growth at $37^{\circ} \mathrm{C}$. cultures were made from 13 different colonies, and the organisms thus isolated tested as described below.

Sample 2 was also obtained at a farm and was the mixed milk of several cows. It was excellent milk and very clean. The procedure was exactly the same as in the case of Sample 1, but cultures were taken from only 10 colonies.

Samples 3, 4, 5 and 6 were obtained in the street from carts belonging to four different dealers who sell milk in this neighbourhood. They were ordinary samples and were examined in the same manner as the two previous samples. The number of colonies sub-cultured was respectively 13, 10, 10 and 10.

Samples 7 and 8 were really only one sample, that is to say, they were portions of the same mixed milk but the method used for isolation was different. In the case of Sample 7, 20 c.c. of milk were centrifugalized for 6 hours and the deposit was spread over the surface of bile salt lactose agar plates. In the case of Sample 8 the procedure was the same as for Samples 1 to 6 . The idea of treating the two portions differently was to ascertain whether preliminary incubation would markedly alter the result. The number of colonies fished were 10 and 11 respectively.

Table I shows that the organisms are practically the same in both cases.

Sample 9 was a mixed milk. Twenty c.c. were centrifugalized for 6 hours and plates made both from the creamy upper layer and from the sediment, 3 plates from each. Next day the plates made from the sediment showed only small round, non-acid colonies consisting of elliptical cells resembling a small yeast. The plates from the creamy layer showed many similar small non-acid colonies and 11 acid colonies. All the latter were sub-cultured.

Samples 10, 11 and 12 were portions of a mixed milk. No. 10, Twenty c.c. were centrifugalized for 6 hours and plates made from the sediment and creamy layer mixed. No. 11, 2 c.c. were put into a tube of bile salt mannite broth and incubated at $37^{\circ} \mathrm{C}$. for 6 hours, when plates were made as before. The broth tube (now called No. 12) was then returned to the incubator, left at blood temperature over-night and next morning a loopful of the culture was spread on the surface of plates. Ten colonies were sub-cultured from each set of plates, and each of these 30 colonies was found to be formed by the same variety of bacillus.

The next six samples were from a single cow. The milk was drawn from all the teats into sterile tubes, at the beginning, in the middle, and at the end of milking, to see if the varieties of lactose fermenters varied with the stage in the process of milking at which the milk was collected. They run in pairs, Nos. 13 and 16 being portions of the first milk, Nos. 14 and 17 of the middle milk, and Nos. 15 and 18 of the end milk. The corresponding members of each pair were treated in the same way.

Samples 13, 14 and 15. Three c.c. put into a sterile test-tube and placed at $37^{\circ} \mathrm{C}$. for 18 hours, when plates were made as before on bile salt lactose agar. Thirty-five 
colonies were sub-cultured from these three sets of plates. The organisms were all staphylococci (orange, white and yellow), and with one exception, all failed to liquefy gelatin in 6 weeks.

These samples were left on the laboratory bench for 48 hours. There was then no smell whatever, and no apparent change in the milk. A drop from each tube put on litmus paper showed a faint trace of acidity.

Samples 16, 17 and 18. Three c.c. were put into a tube of bile salt dulcit broth and kept in ice-chest overnight and then incubated at $37^{\circ} \mathrm{C}$. for 6 hours when plates were made as previously. At the end of 48 hours' incubation there was no growth. The dulcit broth tubes were then put in the incubator for 24 hours when plates were again made from them. Only cocci were present. Four days later plates were once more made from these broth tubes. No growth was obtained.

Samples 19, 20 and 21 were portions of a single milk drawn into sterile tubes at the commencement, middle, and end of milking respectively. Each sample was treated in the same way. A dilution of 1 in 100 of sterile water was made and tubes of nutrient broth were inoculated with 0.1 c.c., 0.25 c.c., 0.5 c.c., 0.75 c.c. and 1 c.c. of this dilution. Tubes of broth were also inoculated with 0.05 c.c. and $0 \cdot 1$ c.c. of undiluted milk. Tubes of bile salt mannite broth were inoculated with 0.05 c.c., $0 \cdot 1$ c.c. and 1 c.c. of undiluted milk. 10 c.c. of undiluted milk were also put into each of 5 sterile test-tubes. All tubes were placed at $37^{\circ} \mathrm{C}$.

Next day inoculations were made on slant agar from all the tubes except those containing 10 c.c. of undiluted milk. From one of these latter a loopful was spread over plates of ordinary lactose agar and of bile salt lactose agar, 3 plates being made from each loop and thus 6 from each sample. All tubes and plates were incubated at $37^{\circ} \mathrm{C}$. Inoculations into mannite broth were made later from each 10 c.c. tube.

The results of the examination were as follows :

Sample 19. Growth in $1 / 100$ th of a c.c. but not in $1 / 130$ th c.c. Only non-liquefying staphylococci were found in all tubes up to 1 c.c. when bacilli were observed to be present. No gas-forming organisms were found in 50 c.c.

Sample 20. Growth in $1 / 20$ th c.c. tube but not either in $1 / 10$ th c.c. and in 1/100th c.c. Only non-liquefying staphylococci in 1 c.c. Bacilli were first found in 10 c.c. No gas-forming organisms were present in 50 c.c.

Sample 21. Growth in $1 / 20$ th c.c. but not in $1 / 100$ th. Non-liquefying staphylococci and a bacillus which produced a yellow pigment were isolated. No gas-forming organisms were present in 50 c.c.

Sample 22. Portions of the whole milking from a single cow : the milk was drawn straight from the udder into a sterile test-tube, and examined in the same way as the three previous samples except that the inoculations into bile salt mannite broth were omitted. The incuba- 
tion temperature was $37^{\circ} \mathrm{C}$. Non-liquefying staphylococci were found in $1 / 100$ th c.c. but not in 1/130th c.c. Bacilli were first noticed in 10 c.c. No gas-forming organisms were found in the 50 c.c. examined.

Sample 23. A portion of the same milk as No. 22 taken from the ordinary milking pail. It was treated as No. 22. Non-liquefying staphylococci were present in $1 / 130$ th c.c. but not in $1 / 200$ th c.c. The further results were exactly as in the case of No. 22 .

Sample 24 was the same milk as No. 23, but after it had been passed through the straining cloth. It was examined in the same way as Nos. 22 and 23. Growth was obtained from the smallest quantity examined, i.e., 1/1000th c.c. Bacilli, and these were liquefiers, occurred first in 1/200th c.c. Gas-forming organisms did not appear until the 10 c.c. tubes were examined. Plates were made from one of these tubes and 10 colonies were sub-cultured.

A sample of the water in which the milk-pails were usually washed was also analysed. The amounts examined were $1 / 10,000$ th, $1 / 1000$ th, 1/100th, 1/10th, 1, 10 and 250 c.c. The incubation temperature was, as before, $37^{\circ} \mathrm{C}$. A growth was obtained from 10 c.c. but not from 1 c.c. Plates were made and 10 pure cultures obtained.

The time of milking of Samples 1, 3, 4, 5 and 6 was not ascertained but was presumably the early morning of the day of examination and, therefore, the analysis was commenced within 5 hours from the time of collection. All the other samples were obtained at one farm. Nos. 2, $7,8,9,10,11$ and 12 were milk as sold at the farm from the 6 a.m. milking and the examination was commenced at about 10 a.m. In the case of Nos. 13 to 24 the cows were milked from 3.30 to 4 p.m., the samples were brought straight to the laboratory and the analysis commenced at once. The cows were milked by the farm people in the manner usual at this farm and beyond collecting the milk samples in sterile tubes no precautions were taken to avoid contamination.

Though gas-forming organisms were not present in Samples 13-23, and though the number of samples is so small, still it may be of interest to compare the results with those of some other workers.

Thus Park (1901, p. 393) found the average bacterial content of the milk from 6 separate cows, examined 5 hours after collection, to be 6000 per c.c., the lowest count being 400 per c.c., and that of 25 cows tested immediately after milking to be 4550 . He used agar plates as " nutrient gelatin was found to be more troublesome and not to yield more accurate results than nutrient agar." Two sets of plates were 
made. One set was incubated at about $20^{\circ} \mathrm{C}$. and counted on the 4th day; the other was put at $37^{\circ} \mathrm{C}$. for 24 hours, and then for a second 24 hours at $20^{\circ} \mathrm{C}$. He states that from 5-30\% more colonies developed on the plates incubated at room temperature than on those kept at $37^{\circ} \mathrm{C}$. for 24 hours. Thus, to compare his lowest count with my results we must deduct $30 \%$ from the 400 which gives 280 per c.c. as his lowest count in the case of milk from a single cow and "when every reasonable means was taken to insure cleanliness."

Burr (1902), also taking every reasonable precaution, found 500 organisms per c.c. in the milk of a single cow. Making, for the purposes of comparison, the same deduction as before we get the number 350 per c.c.

Ed. v. Freudenreich (1902) thought it would be easy to carry out strict asepsis and thus obtain a bacteria-free milk. But he soon came to the conclusion that this was impossible. He found that the milk always contained $200-300$ organisms per c.c. even though the milker's hands and the teats were washed first with soft soap and sterile water, then with servatol soap and sterile water, finally with sterile water alone and dried on a sterile towel; the milker's hands were smeared with lanoline, and the first milk rejected. After all these precautions had been taken the milk was drawn into a sterile funnel and thus into a sterile flask. Twenty-eight cows were milked in this way. The bacterial content of the mixed milk of these 28 cows varied from $65-680$ organisms per c.c. in 18 samples:

\begin{tabular}{|c|c|c|c|c|}
\hline \\
\hline $00-200$ & 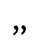 & & & \\
\hline $00-300$ & 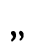 & " & 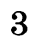 & ” \\
\hline-40 & ” & & 5 & \\
\hline 68 & & " & & \\
\hline
\end{tabular}

The mean was 230 per c.c. Some single flasks were examined and yielded from $55-125$ organisms per c.c.

$\mathrm{He}$ found non-liquefying cocci in greatest numbers. Bacteria were few.

Freudenreich and Thoni (1903) from a further series of similar experiments conclude that freshly drawn milk, even when the most careful precautions are taken against contamination, always contains bacteria, that these are mostly cocci, and that they come from the udder.

Continuing his experiments v. Freudenreich (1903) states that he Journ. of Hyg. vi 
examined the udders and the milk in the udders of 15 cows; in 13 cases immediately after slaughtering. He found none bacteria-free. The organisms were mostly cocci. B. lactis acidi was met with once only. In three cases the ducts were diseased and in these cases the diseased tissues contained fewer organisms than usual. B. coli was never found.

He mentions that Boekhout and de Vries drew milk directly from the udder with a sterile cannula and always got a growth from it.

Lux (1904) examined milk which was drawn in the manner customary in the place. No antiseptic precautions were used. The milk was drawn into sterile test-tubes which were not allowed to touch the teat, and the plug of which was only removed for the few seconds during which the milk was flowing. 260 cow-milk and 95 goat-milk samples were analysed. The medium used was whey agar, the incubation temperature $38^{\circ}$ C., and the count was made on the fourth day. The average per c.c. was 1395 organisms which were mostly non-pathogenic cocci.

Henderson (1904) examined 7 normal udders and obtained growth in $76 \%$ of the cultures made, the organisms being staphylococci, streptococci and pseudo-diphtheria bacilli. None of the organisms were found to be pathogenic to laboratory animals. Two of these normal udders were from young heifers, and were unexpanded, and all the cultures made from the milk cistern, ducts and parenchyma remained sterile.

Willem and Miele (1905) obtained a milk containing 2.5 bacteria per c.c. The milking was done in a special place which was kept as aseptic as possible. The greatest care was taken to ensure the cows being clean. The udder and teats were washed before each milking with soap and boiled water or an antiseptic solution.

From the examples quoted we see that it is impossible to obtain bacteria-free milk but that the organisms in carefully collected milk are not pathogenic to the usual laboratory animals. We may allow then that the presence of such organisms in reasonable number would not render a milk harmful to man. Lux's experiments have shown that with very ordinary care it is possible to obtain a milk containing on an average 1400 bacteria per c.c. and it is obvious that with very slight trouble the number may be much reduced.

The work of Park (1901), Nicolle and Petit (1903), Conn and Esten (1904), Koning (1905), F. C. Harrison (1905), and others, has shown that if milk be rapidly cooled to $11^{\circ} \mathrm{C}$. or below, very little, if any multiplication of organisms takes place for some 12 hours. Therefore 
Park's suggested average standard of not more than 12,000 bacteria per c.c. in warm, and 5000 per c.c. in cold weather, seems a generous standard and one which with a little care should be easily attained.

It is necessary to note that "Separator-milk" must not be judged by the same standard as fresh milk, for. Severin and Budinoff (1905), and Severin (1905), have shown that even when every possible precaution is taken against contamination the milk issuing from the separator always contains many more bacteria than it did before it passed into the separating-chamber. Severin suggests that the mechanical movement completes the separation of bacteria which were only partially divided when they entered the machine.

It may be of interest to mention that Jensen (1903) states that the results of the Copenhagen Hygienic Commission showed that of 142 samples of pasteurised milk 98 samples contained more than 100,000 microbes per c.c.

\section{Tests applied to the organisms isolated.}

All the gas-forming bacilli isolated from the samples described were studied with regard to the following characters:

(1) Morphology. 24-hour agar cultures were used.

(2) Motility. Two separate cultures of each of these organisms were examined microscopically for the presence or absence of motility. On the first occasion 24-hour broth cultures were examined by the hanging drop method with a $\frac{1}{6}$ th objective and $a \times 8$ eyepiece. On the second occasion young broth cultures, about six hours old, were used. A drop of the culture was placed on a slide and examined under dark ground illumination with a $\frac{1}{2}$ in. objective and $a \times 8$ eyepiece. The results were the same in each case. I found the second method the easier and to give in my opinion a better idea of the power of locomotion. Any organism was considered to be motile when there was distinct translation from place to place. No observations were made as to whether there were rotatory or other movements without progressive motion.

(3) Staining by Gram's method.

(4) Production of indol-broth cultures, about 8 to 10 days old, were used. About 1 c.c. of a $0.02 \%$ solution of sodium nitrite was added to each tube and then a few drops of sulphuric acid.

(5) Voges and Proskauer's reaction. 
(6) Gas percentage.

(7) Ratio of $\mathrm{H}$ to $\mathrm{CO}_{2}$.

Fermentation tubes containing $2 \%$ peptone (Witte) and $1 \%$ glucose in tap-water were inoculated with the various organisms and incubated at $37^{\circ} \mathrm{C}$. After 48 hours growth they were taken out of the incubator, allowed to cool, and the amount of gas produced noted. The bulb was then filled with $2 \% \mathrm{NaHO}$ solution, the opening closed with the thumb and the tube thoroughly shaken. After all the gas had been collected in the closed arm the thumb was removed and air allowed to enter the bulb to replace any $\mathrm{CO}_{2}$ absorbed. The ratio of $\mathrm{H}$ to $\mathrm{CO}_{2}$ was then observed and the tubes allowed to stand at room temperature for 48 hours when the presence or absence of Voges and Proskauer's reaction was noted ${ }^{1}$.

(8) Growth of nutrient agar.

(9) " " " gelatin.

(10) " " " broth.

(11) " " litmus milk.

(12) Fermentation of various carbo-hydrates, alcohols, etc.

\section{Characters of the organisms isolated.}

The organisms isolated all had the following characters in common. They were all Gram-negative, non-sporing, bacilli of much the same size and shape and without any special morphological differences. The growths on agar and gelatin were all non-characteristic. Both gelatin stab, and slope cultures were made. Some of the stab cultures showed a

1 I have given all the details of the technique employed because in a recent number of the Bulletin de l'Institut Pasteur, vol. Iv. 1906, p. 250, there is a note to the effect that MacL. Harris has found Voges and Proskauer's reaction to be given by every organism and that, therefore, it is of no value as a distinguishing characteristic. No details of Harris's technique are given. Since reading that note I have re-tested some 20 of the organisms described in this paper. The cultures were incubated for 5 days at $37^{\circ} \mathrm{C}$. and after adding the NaHO allowed to stand for a week: the results were similar to those previously obtained, i.e. certain organisms gave the reaction and others did not. It is, however, quite possible that this reaction may be quantitative and not qualitative and that the substance, acetylmethylcarbinol (Harden, 1906) necessary for the appearance of the red colour may be produced by all bacteria which decompose glucose, but that the quantity produced by some of them from a $1 \%$ solution of glucose in 48 hours may be too small to give rise to any visible colouration on the addition of $\mathrm{NaHO}$.

I can only say that under the conditions given above I have found this reaction of great use in the differentiation of these lactose fermenting bacilli. 
wrinkled surface growth in a week to 10 days but wrinkling was not observed in any of the slope cultures. All produced general turbidity in nutrient broth. In every case litmus milk was acidified and coagulated. All produced acid and gas in glucose, lactose, mannite, sorbit, but not a single one had any effect on erythrit.

The remaining reactions are given in the following Table:

\section{TABLE I.}

\begin{tabular}{|c|c|c|c|c|c|c|c|c|c|c|c|}
\hline $\begin{array}{l}\text { No. of } \\
\text { Sample }\end{array}$ & $\begin{array}{c}\text { No. of } \\
\text { organism }\end{array}$ & $\begin{array}{l}\text { Cane } \\
\text { Sugar }\end{array}$ & Dulcit & Adonit & Inulin & $\begin{array}{l}\text { Gas per- } \\
\text { centage in } \\
\text { Glucose }\end{array}$ & $\mathrm{H} / \mathrm{CO}_{2}$ & $\underset{\text { reaction }}{\mathbf{V} \& \mathbf{P}}$ & Indol & $\begin{array}{l}\text { Lign. of } \\
\text { gelatin }\end{array}$ & Motilit \\
\hline \multirow[t]{13}{*}{1} & 1 & - & - & - & - & 30 & $4 / 1$ & - & + & - & - \\
\hline & 2 & - & - & + & - & 20 & $4 / 1$ & - & + & - & - \\
\hline & 3 & - & - & - & - & 45 & $3 / 1$ & - & + & - & - \\
\hline & 4 & - & - & - & - & 25 & $4 / 1$ & - & + & - & - \\
\hline & 5 & + & - & + & - & 25 & $5 / 1$ & - & + & - & - \\
\hline & 6 & + & + & + & - & 40 & $3 / 1$ & - & + & - & + \\
\hline & 7 & - & + & - & - & 30 & $4 / 1$ & - & + & - & - \\
\hline & 8 & + & - & + & - & 45 & $3 / 1$ & - & + & - & - \\
\hline & 9 & + & + & + & -. & 20 & $5 / 1$ & - & + & - & + \\
\hline & 10 & + & - & + & - & 25 & $5 / 1$ & - & + & - & - \\
\hline & 11 & - & + & - & - & 45 & $5 / 1$ & - & + & - & - \\
\hline & 12 & + & - & + & - & 30 & $5 / 1$ & - & + & - & - \\
\hline & 13 & - & - & - & - & 45 & $3 / 1$ & - & + & - & - \\
\hline \multirow[t]{10}{*}{2} & 14 & - & + & - & - & 25 & $5 / 1$ & - & + & - & - \\
\hline & 15 & - & + & - & - & 30 & $5 / 1$ & - & + & - & + \\
\hline & 16 & - & - & - & - & 45 & $2 / 1$ & - & + & - & - \\
\hline & 17 & - & + & - & - & 20 & $5 / 1$ & - & + & - & - \\
\hline & 18 & - & + & - & - & 45 & $3 / 1$ & - & + & - & - \\
\hline & 19 & - & + & - & - & 30 & $4 / 1$ & - & + & - & - \\
\hline & 20 & - & + & - & - & 11 & $3 / 1$ & - & + & - & - \\
\hline & 21 & - & + & - & - & 25 & $3 / 1$ & - & + & - & + \\
\hline & 22 & - & - & - & - & 25 & $4 / 1$ & - & + & - & - \\
\hline & 23 & - & + & - & - & 40 & $2 / 1$ & - & + & - & - \\
\hline \multirow[t]{13}{*}{3} & 24 & + & - & - & - & 90 & $1 / 2$ & + & - & + & + \\
\hline & 25 & + & - & + & - & 50 & $2 / 1$ & - & - & - & - \\
\hline & 26 & + & - & + & - & 55 & $2 / 1$ & - & - & - & - \\
\hline & 27 & + & - & - & - & 90 & $1 / 2$ & + & - & + & + \\
\hline & 28 & + & - & - & - & 90 & $1 / 2$ & + & - & + & + \\
\hline & 29 & - & - & + & - & 40 & $3 / 1$ & - & + & - & + \\
\hline & 30 & + & + & + & + & 90 & $1 / 1$ & + & + & - & - \\
\hline & 31 & - & + & - & - & 60 & $2 / 1$ & - & - & - & + \\
\hline & 32 & - & + & - & - & 50 & $2 / 1$ & - & - & - & + \\
\hline & 33 & - & + & - & - & 50 & $2 / 1$ & - & - & - & + \\
\hline & 34 & + & - & - & - & 90 & $1 / 2$ & + & - & + & + \\
\hline & $35_{1}$ & - & - & - & - & 60 & $2 / 1$ & - & + & - & - \\
\hline & $35_{2}$ & + & - & + & + & 30 & $3 / 2$ & + & + & - & - \\
\hline
\end{tabular}


TABLE I. (continued).

\begin{tabular}{|c|c|c|c|c|c|c|c|c|c|c|c|}
\hline $\begin{array}{l}\text { No. of } \\
\text { Sample }\end{array}$ & $\begin{array}{c}\text { No. of } \\
\text { organism }\end{array}$ & $\begin{array}{l}\text { Cane } \\
\text { Sugar }\end{array}$ & Dulcit & Adonit & Inulin & $\begin{array}{l}\text { Gas per- } \\
\text { centage in } \\
\text { Glucose }\end{array}$ & $\mathrm{H} / \mathrm{CO}_{2}$ & $\underset{\text { reaction }}{\mathrm{V} \& \mathrm{P}}$ & Indol & $\begin{array}{l}\text { Lign of } \\
\text { gelatin }\end{array}$ & Motilit \\
\hline \multirow[t]{10}{*}{4} & 36 & + & - & - & - & $90^{\circ}$ & $2 / 3$ & + & - & + & + \\
\hline & 37 & + & - & - & - & 90 & $1 / 2$ & + & - & + & + \\
\hline & 38 & + & - & - & - & 80 & $2 / 3$ & + & - & + & + \\
\hline & 39 & + & - & - & - & 90 & $1 / 1$ & + & - & + & + \\
\hline & 40 & + & - & - & - & 80 & $1 / 1$ & + & - & + & + \\
\hline & 41 & + & - & + & + & 30 & $2 / 1$ & + & - & - & - \\
\hline & 42 & + & - & + & - & 60 & $3 / 2$ & - & - & - & - \\
\hline & 43 & + & - & - & - & 60 & $1 / 2$ & + & - & + & + \\
\hline & 44 & + & + & + & + & 80 & $1 / 1$ & + & - & - & - \\
\hline & 45 & + & + & + & + & 70 & $2 \nmid 1$ & + & - & - & - \\
\hline \multirow[t]{10}{*}{6} & 46 & + & - & + & - & 100 & $1 / 2$ & + & - & - & - \\
\hline & 47 & + & + & + & - & 75 & $3 / 2$ & + & $\therefore$ & - & - \\
\hline & 48 & + & - & + & - & 90 & $2 / 3$ & + & - & - & - \\
\hline & 49 & - & + & - & - & 50 & $3 / 1$ & - & + & - & + \\
\hline & 50 & - & + & - & - & 65 & $2 / 1$ & - & + & - & + \\
\hline & 51 & - & + & - & - & 45 & $3 / 1$ & - & + & - & + \\
\hline & 52 & - & + & - & - & 50 & $3 / 1$ & - & + & - & + \\
\hline & 53 & - & + & - & - & 50 & $3 / 1$ & - & + & - & + \\
\hline & 54 & - & + & - & - & 50 & $3 / 1$ & - & + & - & + \\
\hline & 55 & - & + & - & - & 25 & $3 / 1$ & - & + & - & + \\
\hline \multirow[t]{10}{*}{6} & 56 & - & + & - & - & 40 & $2 / 1$ & - & + & - & - \\
\hline & 57 & - & + & - & - & 40 & $7 / 1$ & - & + & - & - \\
\hline & 58 & + & + & - & - & 30 & $3 / 1$ & - & + & - & - \\
\hline & 59 & - & + & - & - & 50 & $3 / 1$ & - & + & - & - \\
\hline & 60 & - & + & - & - & 50 & $3 / 1$ & - & + & - & - \\
\hline & 61 & - & + & - & - & 45 & $3 / 1$ & - & + & - & - \\
\hline & 62 & - & + & - & - & 20 & $3 / 1$ & - & + & - & - \\
\hline & 63 & - & + & - & - & 40 & $3 / 1$ & - & + & -- & - \\
\hline & 64 & - & + & - & - & 50 & $3 / 1$ & - & + & - & - \\
\hline & 65 & - & + & - & - & 30 & $2 / 1$ & - & + & - & - \\
\hline \multirow[t]{10}{*}{7} & 66 & - & + & - & - & 50 & $2 / 1$ & - & + & - & - \\
\hline & 67 & + & + & + & + & 90 & $1 / 1$ & + & + & - & - \\
\hline & 68 & + & + & + & + & 90 & $1 / 1$ & + & + & - & - \\
\hline & 69 & -. & + & - & - & 30 & $2 / 1$ & - & + & - & - \\
\hline & 70 & - & + & - & - & 40 & $2 / 1$ & - & + & - & - \\
\hline & 71 & - & + & - & - & 25 & $3 / 1$ & - & + & - & - \\
\hline & 72 & - & + & - & - & 25 & $3 / 1$ & - & + & - & - \\
\hline & 73 & - & + & - & - & 25 & $5 / 1$ & - & + & - & - \\
\hline & 74 & + & + & - & - & 40 & $2 / 1$ & - & + & - & - \\
\hline & 75 & + & + & - & - & 50 & $2 / 1$ & - & + & - & - \\
\hline \multirow[t]{7}{*}{8} & 76 & - & + & - & - & 40 & $4 / 1$ & - & + & - & - \\
\hline & 77 & - & + & - & - & 25 & $2 / 1$ & .- & + & - & - \\
\hline & 78 & - & + & - & - & 20 & $2 / 1$ & - & + & - & - \\
\hline & 79 & - & + & - & - & 40 & $2 / 1$ & - & + & - & - \\
\hline & 80 & + & + & - & - & 40 & $2 / 1$ & - & + & - & - \\
\hline & 81 & - & + & - & - & 50 & $2 / 1$ & - & + & - & - \\
\hline & 82 & + & + & - & - & 50 & $2 / 1$ & - & + & - & - \\
\hline
\end{tabular}


TABLE I. (continued).

\begin{tabular}{|c|c|c|c|c|c|c|c|c|c|c|c|}
\hline $\begin{array}{l}\text { No. of } \\
\text { Sample }\end{array}$ & $\begin{array}{c}\text { No. of } \\
\text { organism }\end{array}$ & $\begin{array}{l}\text { Cane } \\
\text { Sugar }\end{array}$ & Dulcit & Adonit & Inulin & $\begin{array}{l}\text { Gas per- } \\
\text { centage in } \\
\text { Glucose }\end{array}$ & $\mathrm{H} / \mathrm{CO}_{2}$ & $\underset{\text { reaction }}{\mathbf{V} \& \mathbf{P}}$ & Indol & $\begin{array}{l}\text { Lign. of } \\
\text { gelatin }\end{array}$ & Motility \\
\hline \multirow[t]{5}{*}{8} & 83 & - & + & - & - & 25 & $3 / 1$ & - & + & - & - \\
\hline & 84 & - & + & - & - & 25 & $2 / 1$ & - & + & - & - \\
\hline & 85 & + & + & + & + & 80 & $3 / 2$ & + & + & - & - \\
\hline & $86^{1}$ & - & - & - & - & 20 & $2 / 1$ & - & + & - & + \\
\hline & \multicolumn{11}{|c|}{1 Lactose - } \\
\hline \multirow[t]{11}{*}{9} & 87 & + & + & + & + & 70 & $1 / 1$ & + & + & - & - \\
\hline & 88 & + & + & + & + & 90 & $1 / 1$ & + & + & - & - \\
\hline & 89 & + & + & + & + & 25 & $2 / 1$ & + & + & - & - \\
\hline & 90 & + & + & + & + & 80 & $1 / 1$ & + & + & - & - \\
\hline & 91 & + & + & + & + & 85 & $1 / 1$ & + & $\perp$ & - & - \\
\hline & 92 & + & + & + & + & 80 & $1 / 1$ & + & + & - & - \\
\hline & 93 & + & + & + & + & 95 & $1 / 1$ & + & + & - & - \\
\hline & 94 & + & + & + & + & 80 & $1 / 1$ & + & + & - & - \\
\hline & 95 & + & + & - & - & 50 & $2 / 1$ & - & + & - & + \\
\hline & 96 & + & + & + & + & 70 & $1 / 1$ & + & + & - & - \\
\hline & 97 & + & + & + & + & 80 & $1 / 1$ & + & + & - & - \\
\hline 10 & 98-107) & & & & & & & & & & \\
\hline 11 & $108-117\}$ & - & + & - & - & $10-25$ & $2-4 / 1$ & - & + & + & + \\
\hline 12 & 118-127 & & & & & & & & & & $\begin{array}{l}\text { only in } \\
\text { the cold }\end{array}$ \\
\hline
\end{tabular}

Lactose and mannite were fermented very slowly -7 days. Cultures white at first. Yellow pigment developed in 7 days.

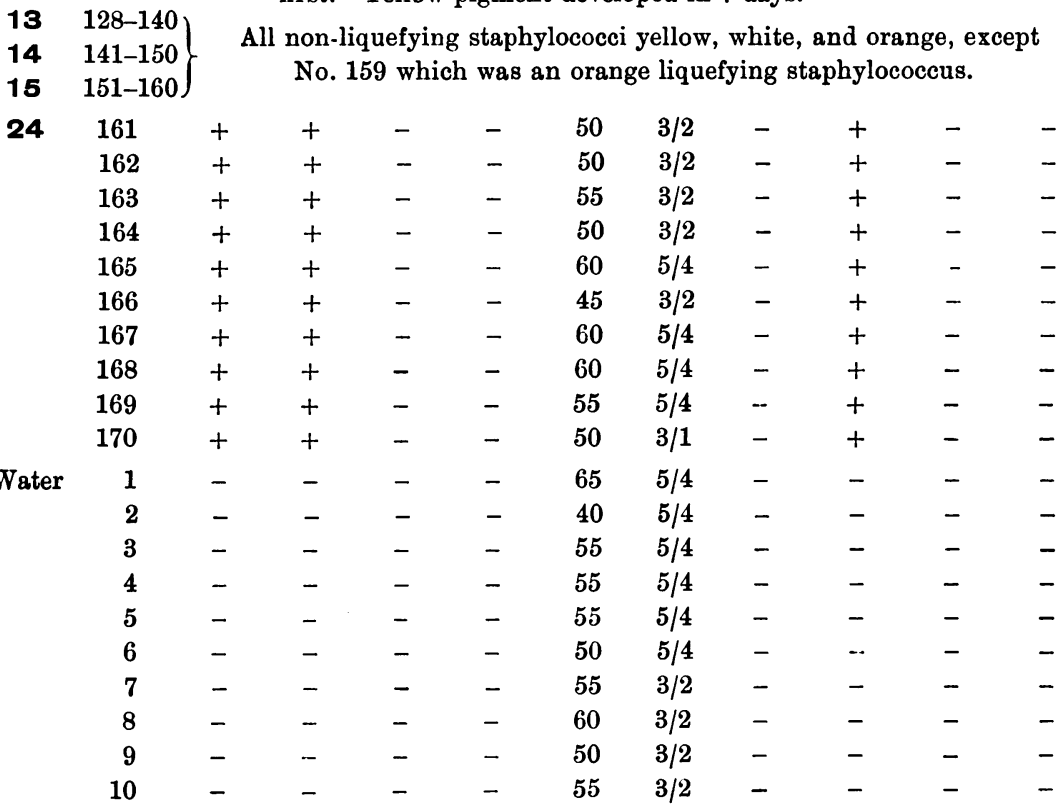

$+=$ the production of acid and gas, or of Voges and Proskauer's reaction, or of indol, or of liquefaction of gelatin, or the presence of motility as the case may be.

- = a negative result.

$\mathrm{V} \& \mathrm{P}=$ Voges and Proskauer's " Kalilaugeroth-reaction." 
These may, as in my previous article, be arranged in groups according to the action they have on cane sugar and dulcit.

Group I = Both cane sugar and dulcit unaffected.

" II = Cane sugar unaffected-dulcit fermented.

„ III = Both cane sugar and dulcit fermented.

" IV = Cane sugar fermented-dulcit unaffected.

\begin{tabular}{cccccc}
$\begin{array}{c}\text { No. of } \\
\text { Sample }\end{array}$ & Group I & Group II & Group III & Group IV & $\begin{array}{c}\text { No. of organisms } \\
\text { isolated }\end{array}$ \\
1 & 5 & 2 & 2 & 4 & 13 \\
2 & 2 & 8 & - & - & 10 \\
3 & 2 & 3 & 1 & 7 & 13 \\
4 & - & - & 2 & 8 & 10 \\
5 & - & 7 & 1 & 2 & 10 \\
6 & - & 9 & 1 & - & 10 \\
7 & - & 6 & 4 & - & 10 \\
8 & - & 7 & 3 & - & 10 \\
9 & - & - & 11 & - & 11 \\
24 & - & - & 10 & - & 10 \\
\hline & 9 & 42 & 35 & 21 & 107
\end{tabular}

If these numbers be calculated as percentages and compared with the numbers previously obtained with cow faeces (MacConkey, 1905) a parallelism in the group percentages is at once apparent,

$\begin{array}{lclll}\text { Country Milks } & 8.4 \% & 39 \cdot 2 \% & 32.7 \% & 19 \cdot 6 \% \\ \text { Cow faeces } & 16.6 & 25 \cdot 0 & 47 \cdot 9 & 12 \cdot 5\end{array}$

and it is obvious that Groups II and III form the majority in both cases.

Again, if we arrange these samples according to the opportunities which have presumably occurred for contamination to take place and then calculate the group percentages, an interesting point is brought out :

\begin{tabular}{lccccc}
\multicolumn{1}{c}{ Samples } & Group I & Group II & Group III & Group IV & $\begin{array}{c}\text { Total No. of } \\
\text { organisms isolated }\end{array}$ \\
$2,7,8,9,24$ & $3.9 \%$ & $41 \cdot 1 \%$ & $54 \cdot 9 \%$ & - & 51 \\
$1,3,4,5,6$ & $12 \cdot 5$ & $37 \cdot 5$ & 12.5 & $37 \cdot 5 \%$ & 56 \\
Town milk & 32.5 & 15 & 20 & $32 \cdot 5$ & 40
\end{tabular}

From which it would seem that the farther we get from the source the greater the change in the group proportions. Thus nearest the source we find Groups II and III taken together forming $96 \%$ of the organisms isolated. A short distance away they form $50 \%$, and still further away the number decreases to $35 \%$. While Groups I and IV increase from $3.9 \%$ at the source to $65 \%$ at the point farthest away. 


\section{A. MacConkey}

Having thus considered these organisms as members of various groups we may now study them individually and compare them with certain known organisms whose reactions have been worked out and gathered together in Table II. This list is longer than the one

\section{TABLE II.}

\begin{tabular}{|c|c|c|c|c|c|c|c|c|c|c|}
\hline & $\begin{array}{l}\text { Cane } \\
\text { Sugar }\end{array}$ & Dulcit & Adonit & Inulin & $\begin{array}{l}\text { Gas per- } \\
\text { centage in } \\
\text { Glucose }\end{array}$ & $\mathrm{H} / \mathrm{CO}_{2}$ & $V \& P$ & Indol & $\underset{\substack{\text { Lign } \\
\text { gelatin }}}{\text { of }}$ & Motili \\
\hline B. Grïnthal & - & - & - & - & 50 & $3 / 1$ & - & + & - & + \\
\hline B. levans & - & - & - & + & 60 & $1 / 2$ & + & - & + & + \\
\hline $\left.\begin{array}{l}\text { B. acidi lactici } \\
\text { (Hüppe), Král }\end{array}\right\}$ & - & - & + & - & 30 & $2 / 1$ & - & + & - & - \\
\hline $\begin{array}{l}\text { B. acidi lactici } \\
\text { (Hüppe), St George's }\end{array}$ & \}- & - & + & - & 15 & $3 / 1$ & - & + & - & - \\
\hline B. coli communis & - & + & - & - & 25 & $2 / 1$ & - & + & - & + \\
\hline $\begin{array}{l}\text { B.cavicida, (Brieger) } \\
\text { Pasteur }\end{array}$ & - & + & - & - & 20 & $3 / 1$ & - & + & - & + \\
\hline $\begin{array}{l}\text { B.cavicida, (Brieger) } \\
\text { Král }\end{array}$ & - & + & - & - & 25 & $3 / 1$ & - & + & - & + \\
\hline B. mustelae septicus & - & + & - & - & 25 & $3 / 1$ & - & + & - & + \\
\hline B. Neapolitanus, Král & + & + & - & - & 30 & $2 / 1$ & - & + & - & - \\
\hline B. rhinoscleromatis, $\mathrm{W}$. & + & + & + & - & 40 & $3 / 1$ & - & + & - & - \\
\hline " $\quad, \quad$ R. & + & + & + & - & 40 & $3 / 1$ & - & + & - & - \\
\hline $\begin{array}{c}\text { B. pneumoniae (Fried- } \\
\text { länder), } \mathrm{N} .\end{array}$ & + & + & + & - & 30 & $3 / 1$ & - & + & - & - \\
\hline $\left.\begin{array}{c}\text { B. pneumoniae (Fried- } \\
\text { länder), Nic. }\end{array}\right\}$ & + & + & + & - & 30 & $3 / 1$ & - & + & - & - \\
\hline $\left.\begin{array}{c}\text { B. pneumoniae (Fried- } \\
\text { länder), A. }\end{array}\right\}$ & + & + & + & - & 35 & $3 / 1$ & - & + & - & - \\
\hline $\left.\begin{array}{c}\text { B. pneumoniae (Fried- } \\
\text { länder), Král }\end{array}\right\}$ & + & + & + & - & 35 & $3 / 1$ & - & + & - & - \\
\hline $\left.\begin{array}{c}\text { B. pneumoniae (Fried- } \\
\text { länder), Allen }\end{array}\right\}$ & + & + & + & - & 35 & $3 / 1$ & - & + & - & - \\
\hline $\left.\begin{array}{c}\text { B. oxytocus pernicio- } \\
\text { sus, Král }\end{array}\right\}$ & + & + & + & + & 60 & $1 / 1$ & + & - & - & - \\
\hline B. lactis aerogenes & + & - & + & - & $25^{1}$ & $2 / 1^{1}$ & + & + & - & - \\
\hline $\begin{array}{l}\text { B. capsulatus (Pfeiffer), } \\
\text { Pasteur }\end{array}$ & + & - & + & - & $25^{1}$ & $2 / 1^{1}$ & + & + & - & - \\
\hline $\begin{array}{l}\text { B.capsulatus (Pfeiffer), } \\
\text { Král }\end{array}$ & + & - & + & - & $60^{1}$ & $2 / 3^{1}$ & + & + & - & - \\
\hline $\left.\begin{array}{l}\text { B. cloacae (Jordan), } \\
\text { Jordan }\end{array}\right\}$ & + & - & - & - & 75 & $1 / 1$ & + & - & + & + \\
\hline $\begin{array}{l}\text { B. cloacae (Jordan), \} } \\
\text { Král }\end{array}$ & + & - & - & - & 50 & $1 / 1$ & + & - & + & + \\
\hline B. coscoroba & + & - & - & - & 40 & $3 / 1$ & - & + & - & - \\
\hline
\end{tabular}

$+=$ production of acid and gas, of Voges and Proskauer's reaction, or of indol, or of liquefaction of gelatin, or the presence of motility as the case may be. $-=$ a negative result.

V \& P = Voges and Proskauer's " Kalilaugeroth-reaction."

1 On this occasion $B$. lactis aerogenes and $B$. capsulatus (Pfeiffer), Pasteur, gave results which were smaller than those given by $B$. capsulatus (Pfeiffer), Král, which gave the usual percentage and ratio. 
previously given and I beg to thank Dr J. Binot of the Pasteur Institute, Paris, for so kindly sending me the following cultures: B. rhinoscleromatis W., do. R., B. pneumoniae (Friedländer), W., do. Nic., do. A., B. cavicida (Brieger), B. capsulatus (Pfeiffer), B. coscoroba. To Prof. E. O. Jordan I am greatly indebted for a culture of $B$. cloacae, to Dr H. de R. Morgan for B. Grünthal, to Dr R. M. Allen for B. Friedländer (Allen) and to Dr H. Spitta for B. acidi lactici (Hüppe), $\mathrm{St}$ George's. From Král's laboratory I obtained B. cavicida (Brieger), K., B. levans, B. mustelae septicus, B. oxytocus perniciosus.

As B. levans, B. coscoroba and B. oxytocus perniciosus are not so well known as most of the others the following notes may be of interest.

Holliger (1902) cites Wolffin (1894) as describing the B. levans to be the cause of the fermentation of dough and to be in all probability identical with $B$. coli. According to Wolffin's description the $B$. levans is :- "A facultative anaerobic rod $1 \cdot 8 \mu \times 0.6 \mu$. No threads are formed in cultures. It is non-sporing. In most cultures it is indistinguishable from $B$. coli but it does not produce indol, and does not coagulate milk. It ferments dextrose with a ratio of $\mathrm{H}: \mathrm{CO}_{2}=1: 3$. Lactose is not attacked." However, both F. Frankel and J. Papasotiriu found that it produced indol and caused acidity and coagulation in milk.

Holliger found two bacilli in fermenting dough : (1) A motile liquefying bacillus which produced a yellow pigment; and (2) A non-chromogenic liquefying bacillus. Both fermented dextrose and lactose and coagulate milk. The rate of liquefaction varied very much; the white bacillus sometimes taking 1--2 months. No. 1 resembled No. 2 in that at first the growths were not yellow. He compared these bacilli with a B. levans from Král's laboratory and found it and the white bacillus to be identical. The ratio of $\mathrm{H}$ to $\mathrm{CO}_{2}$ was as 1 to 2 . Indol was formed by all three.

The yellow bacillus found in samples 10, 11 and 12 agrees in many respects with Holliger's yellow bacillus.

B. coscoroba (Ann. de l'Inst. Pasteur, 1900) is stated to be the cause of an epidemic which occurred in a particular race of swans, "Cygne de Coscoroba."

B. oxytocus perniciosus Wyssokowitsch. A reference to this bacillus may be found in Teisi Matzuschita's Bakteriologische Diagnostik, 1902, p. 452. He states that it was isolated from stale milk.

All these organisms fermented glucose, lactose, galactose, laevulose, mannose, arabinose, raffinose, mannite, sorbit, dextrin.

Erythrit was not attacked in one single case.

They all produced acidity and caused clotting in litmus milk. In the case of the Friedländer bacilli and the two B. rhinoscleromatis the coagulation occurred very late, i.e. in 14 to 21 days.

It has been suggested that organisms may vary so much as regards their fermentative powers that these reactions are of only slight, if any, value 
as differentiating characteristics. Therefore before proceeding further it is necessary to consider briefly the question of how much reliance may be placed upon these fermentation tests as a means of differentiating and identifying these organisms. It is true that it is not an uncommon laboratory experience to find that an organism if left uncultivated for some time has lost part of its fermenting power. Such loss, however, is not permanent and a few sub-cultures soon restore the former vigour. The cause of such temporary weakening has not been discovered and seems inexplicable in view of the unfavourable conditions to which organisms have been subjected without loss, even temporary, of power. Thus, as I have previously shown, B. coli communis can be kept under most unfavourable conditions for about 1 year without losing any of its vigour. The following experiment also bears upon this point. On November 1st, 1905, I inoculated a gelatin tube with $B$. cloacae and sealed up the tube in the flame. The culture was placed at $37^{\circ} \mathrm{C}$. for about 24 hours and then left on the laboratory bench in a glass jar exposed to diffuse daylight from a north window until May 11th, 1906, i.e., over six months. An examination of the tube on this date showed that the gelatin was completely liquefied and was perfectly clear and transparent above the growth deposited at the bottom of the tube. After shaking to diffuse the growth throughout the gelatin sub-cultures were made in various media and it was found that the fermentation reactions were just the same as before and took place with just as much vigour, showing that an autolysis of six months duration had not impaired the vitality of the bacillus.

Again, if these fermentative reactions are so very variable we should expect to find that different strains of the same organism, which had been kept in different laboratories and most likely grown on media of varying composition for varying lengths of time, would show differences in their behaviour to various fermentable substances. But this does not appear to be the case. A glance at Table II will show that all the Friedländer bacilli react alike; both $B$. cloacae act in the same way; identical results are given by the two strains of $B$. acidi lactici (Hüppe), and so on. Further, I tested 15 different races of the B. typhosus with regard to this point. The ages of the strains varied very much. One had been grown on artificial media for 16 years, another for 10 years, and the others for varying lengths of time; the youngest having been isolated from a typhoid stool only a week or two previously. All these 15 races behaved exactly alike as regards the reactions tested. Now, if a strain 16 years old does not differ from one only a week or two 
old, surely these characters may be considered to be comparatively stable.

We may also consider the question from another point of view. We may start with the postulate that a substance which is decomposed by a large number is a more easily fermentable substance than one which is split up by only a small number of organisms. Now, if we examine Table I we find that dulcit was fermented by 77 organisms, cane sugar by 56 , and adonit by 32 . Therefore, we would be probably justified in presuming that bacteria find adonit more difficult to decompose than either dulcit or cane sugar. Consequently, if an organism fermented all these substances and, owing to unfavourable environment or any other cause, began to lose some of its vigour, we should expect the power of fermenting adonit to fail first. The reaction of a certain number of the organisms in the Tables will be found to uphold this hypothesis but, on the other hand, many will be found to contradict it, and the B. acidi lactici is an example of a bacillus which, on this hypothesis, has retained the power of fermenting the most stable substance while it has lost the power of attacking the less stable bodies.

If we entertain the opposite hypothesis and consider that all the positive reactions are acquired, we are brought up by the $B$. levans which would then have acquired the power of fermenting inulin before that of acting upon dulcit, cane sugar, or adonit.

Besides, on one of these hypotheses we should expect to find organisms like the $B$. Grünthal most numerous whereas such is not the case in these experiments; nor did it occur in my previous ones, where out of 480 lactose fermenters only 25 per cent. belonged to the first group. Or, to take a more special case, out of 75 organisms isolated from time to time out of a mixture of human faeces and tap-water only 6 did not attack either cane sugar or dulcit, and these 6 were found in the early part of the experiment, whereas, if the "loss of power" hypothesis be correct, the number of these organisms should have shown an increase as the experiment progressed and the environment became more and more unfavourable, and at the end should have reached a larger proportion than 6 out of 75 .

Again, we may suppose the fermentative powers of these bacilli to be very variable and we may apply a number of tests to them. In these circumstances we would expect to obtain as many varieties of bacilli as there are combinations of tests. The following Tables show the number of possible combinations of the tests applied and consequently the number of possible varieties of bacilli, together with the varieties actually obtained. 


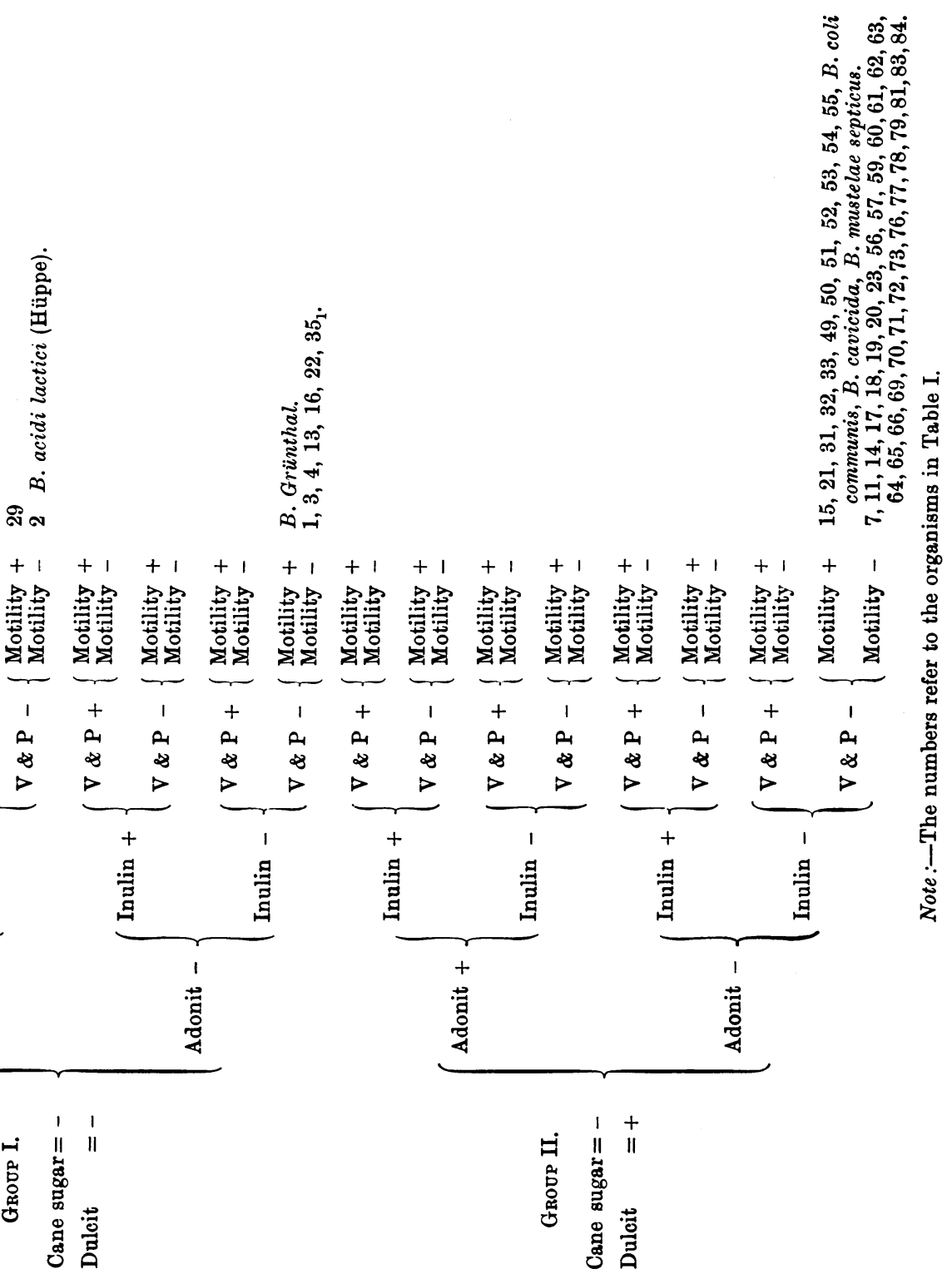




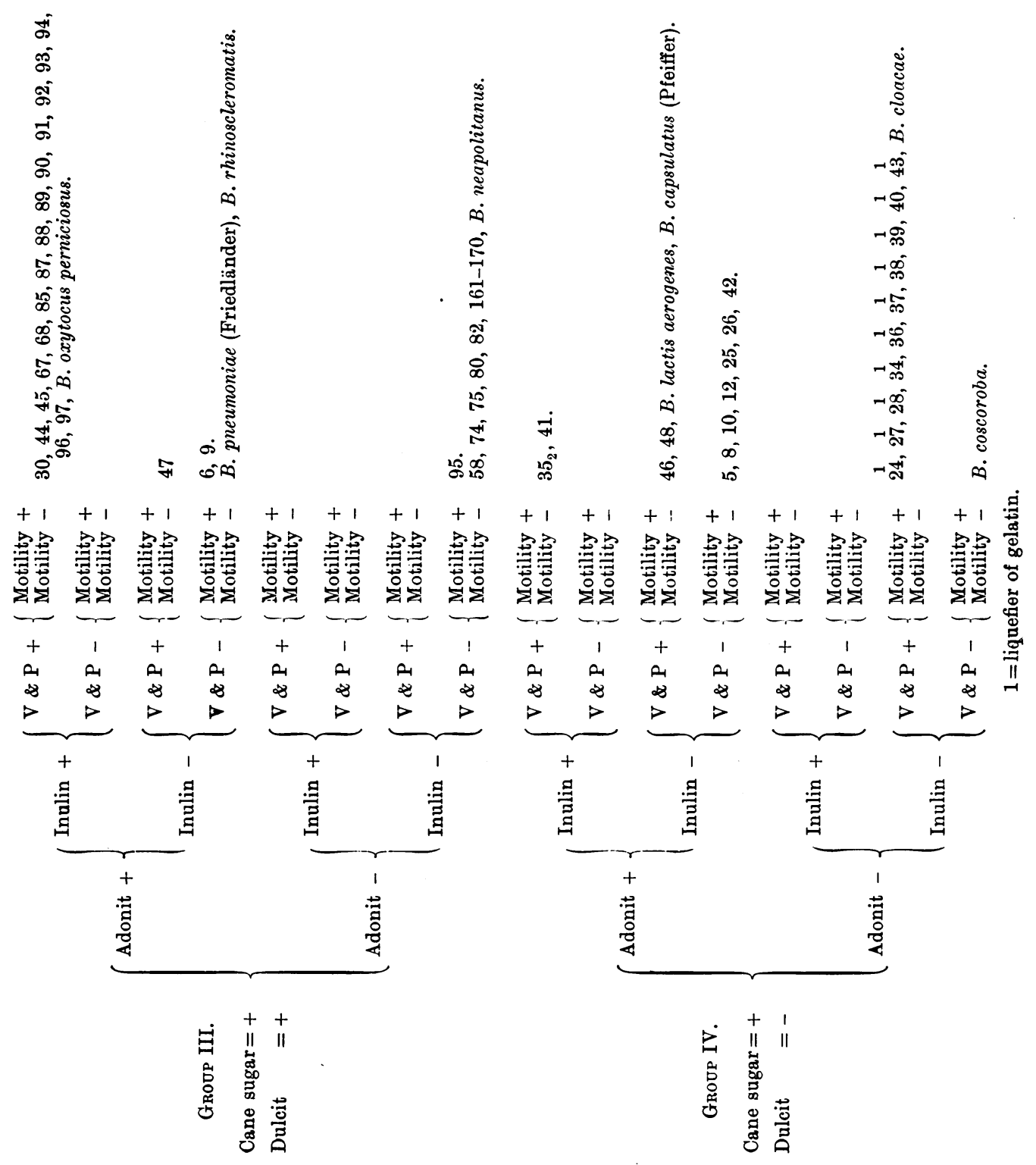


We find that the number of varieties isolated falls very far short of the number possible in the circumstances. The most striking result is shown in Group II where 42 organisms are divided into only two varieties and these differ from each other with regard to one point only, i.e. the presence or absence of motility.

All these points which I have mentioned appear to me to be greatly in favour of accepting fermentation reactions as a means of differentiating and identifying these organisms.

Proceeding on these lines it will be found that of the known organisms the
B. acidi lactici (Hüppe) has been isolated once,
B. coli communis
12 times,
B. neapolitanus
B. lactis aerogenes
B. cloacae
B. oxytocus perniciosus

\begin{tabular}{|c|c|c|}
\hline , & ״ & 12 times, \\
\hline$"$ & ” & $15 \quad$ \\
\hline " & $"$ & twice, \\
\hline & " & 10 times, \\
\hline & , & 16 \\
\hline
\end{tabular}

while the B. Grünthal, B. pneumoniae (Friedländer), and B. coscoroba have not been met with at all.

It must be carefully noted that all the samples which contained gasforming organisms were milks which had been drawn into one vessel and then passed through a strainer into another vessel and possibly into several others before being sold. There was, therefore, plenty of opportunity for contamination to occur. It is precisely in those samples which, as far as one can judge, were most exposed to contamination that we find $B$. lactis aerogenes and $B$. cloacae.

In the samples drawn direct from the cow no gas-forming organisms were met with. These results agree on most points with those obtained by other workers. v. Freudenreich (1902) expresses the opinion that in milk drawn direct into sterile tubes one usually finds only cocci present. v. Freudenreich and Thoni (1903) conclude that lactic acid bacilli are not found in freshly drawn milk. v. Freudenreich (1903) never found $B$. coli in the examination of 15 udders and of the milk in them. v. Freudenreich (1904) never found $B$. coli or B. lactis aerogenes in the udder and only once in milk taken direct into sterile glasses. In the latter case he thinks it was a contamination. Moreover he did not test the gas-producing power of this organism. $\mathrm{He}$ mentions the interesting fact that he found on his plates coli-like and aerogenes-like colonies which were formed of cocci, and also aerogenes-like colonies of a non-gas-forming bacterium, and coli-like colonies of a bacterium which did not ferment milk sugar. 
Lux (1904) found B. coli and B. lactis aerogenes taken together in $9 \%$ of his samples. But he took no precautions as regards cleaning the udder.

Burr (1902) instituted several series of experiments to ascertain the source of the acid organisms of milk and cream. He took great care to have the stables, cows, and everything connected with them thoroughly clean. In milk drawn straight into test-tubes he did not find lactic acid bacilli but they were found in the cream of milk drawn into a sterile pail (cf. Sample 9). Plates exposed under the cows for 10, 20, 30 and 40 seconds during milking all contained $B$. lactis aerogenes, $B$. acidi lactici II, but no B. acidi lactici I. Tubes of sterile milk exposed about the barn and under the cows contained in nearly every case all the varieties of bacilli mentioned, while milk taken at the same time direct from the udder did not contain any. He also examined the glandular part, the milk cistern, and the beginning of the teat of two udders, and failed to find any of these three bacilli.

He concludes that the lactic acid organisms, $B$. lactis aerogenes, $B$. acidi lactici II and I-the latter organism being the B. acidi lactici of Huippe, Marpmann and Esten,-are a contamination from outside the udder. B. acidi lactici II and $B$. lactis aerogenes are commonly very abundant in the stable, while $B$. acidi lactici $\mathrm{I}$, though almost universally present, exists in relatively small numbers.

Conn (1902) considers that the milk bacteria come seldom from the milk passages but chiefly from sources distinct from the cow.

Harrison (1905) examined the milk of 25 cows. The udders and flanks were brushed and wiped with a damp cloth, the first milk was rejected and the samples then taken in sterile test-tubes. From the milk of two of these cows gas-producing bacteria were isolated. $\mathrm{He}$ gives the characteristics of seven organisms isolated from the udder. In the case of six of them the ratio $\frac{\mathrm{H}}{\mathrm{CO}_{2}}=\frac{1}{1+}$ and cane sugar was fermented. Two of these were motile so that it is not at all unlikely they were $B$. cloacae. He mentions that Moor and Ward have also isolated gas-producing bacilli from the udders of certain cows but that it is evidently an exceptional state of affairs. Altogether he isolated 48 gas-producing organisms from various samples of milk. 21 of these gave a gas ratio of $\frac{1}{1}$ or $\frac{1}{1+}$ and 37 fermented cane sugar. Of these latter five were motile.

Savage (1906) as the result of his investigations found that milk 
from individual cows yielded $B$. coli in $17.5 \%$ of the samples. In 11 mixed milks collected fresh at the farm and examined within three hours B. coli was present in $36 \%$, and in 16 shop samples and mixed milk samples, not examined at once, they were present in $94 \%$ of the samples.

Heinemann (1905) considers that the lactic ferments are of intestinal origin and are present in milk owing to contamination with faeces.

It seems then to be the general opinion that gas-forming bacteria are not normally present in milk but that they gain access to it because of want of care and cleanliness during the milking and in connection with the various vessels in which the milk is stored. This opinion is quite borne out by the results of the experiments detailed in this paper.

\section{Summary.}

With ordinary care and cleanliness it is possible to obtain milk which, when freshly drawn, contains less than 1500 organisms per cubic centimetre.

Freshly drawn milk should not contain gas-forming organisms in at least 50 c.c.

Gas-forming organisms are present in milk owing to contamination with faecal material. Of these organisms the B. oxytocus perniciosus, the B. neapolitanus and the B. coli communis occur in greatest number in fresh milk, while the $B$. cloacae and $B$. lactis aerogenes appear at a later stage.

Out of 107 non-chromogenic lactose fermenters isolated from milk only one bacillus gave the reactions of the B. acidi lactici (Hüppe); while the B. Grünthal, B. pneumoniae (Friedländer), and the B. coscoroba have not been met with once.

Finally, I desire to enter a plea for the substitution of certain fermentation reactions in the place of some of the tests now usually employed, in the routine examination of water and food-stuffs, to identify these organisms. At present bacteriologists make use of some, or all, of the following tests:

1. Morphology.

2. Motility.

3. Staining by Gram's method.

4. Character of the growth on nutrient gelatin. 
5. Liquefaction of gelatin.

6. Action on milk.

7. Formation of indol.

8. Fermentation of glucose.

$9 . \quad, \quad$ " lactose.

10. " " cane sugar.

11. Action on neutral-red.

All the organisms mentioned in Tables I and II produced clotting in milk, fermented glucose, gave the neutral-red reaction, had much the same morphology, and the growths on agar and gelatin did not afford any assistance towards differentiating between them.

I would therefore suggest that instead of five of the tests, Nos. 4, 6, 7, 8 and 11, we should substitute the following:

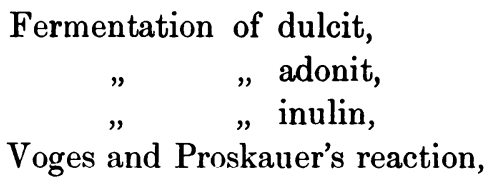

as by so doing we should get a finer differentiation without increase in work and we should not be classing as $B$. coli organisms which may have little in common with, and have a distribution entirely different from that of the B. coli communis.

\section{REFERENCES.}

Boekhout and De Vries (1904), Centralbl. J. Bakteriol., Abt. II. Bd. xiI. pp. 89-93.

Burr, Rollin H. (1902), Ibid. Bd. viII. pp. 236-241.

Cons, H. W. (1902), Ref. Ibid. p. 442.

Conn, H. W. and Esten, W. M. (1904), Reprints of Studies from Rockefeller Institute for Med. Research, 1904.

Delépine, S. (1903), Journ. of Hygiene, vol. III. p. 68.

Freudenreich, Ed. von (1902), Centralbl. f. Bakteriol., Abt. II. Bd. viII. pp. $674-681$.

Freudenreich and Thoni (1903), 1bid. Bd. x. p. 305.

- (1903), Ibid. pp. 401--423.

- (1904), lbid. Bd. xIII. pp. 281-407.

Harden, A. (1906), Proc. of the Royal Society, B. vol. Lxxvir. p. 424.

Harrison, F. C. (1905), Centralbl.f. Bakteriol., Abt. II. Bd. xiv. p. 359.

Harris, N. MacL. (1905), Ref. Bull. de l'Inst. Pasteur, vol. Iv. p. 249.

Heinemans, (1905), Ref. Ibid. p. 246. 
Henderson, J. (1904), Journ. of the Royal Sanitary Institute, vol. xxv. p. 563.

Holliger, W. (1902), Centralbl.f. Bakteriol., Abt. II. Bd. Ix. p. 305.

Jensen, C. O. (1903), "Grundriss der Milchkunde und Milchhygiene." Ref. Centralbl. f. Bakteriol., Abt. II. Bd. xiv. 1905, p. 228.

Koning (1905), Ref. Centralbl. f. Bakteriol.. Abt. II. Bd. xiv. p. 424.

Lux, A. (1904), Ibid. Bd. xI. pp. 195-201.

MACConkey, A. T. (1905), Journ. of Hygiene, vol. v. p. 333.

Nicolie, C. and Petit, P. (1903), Revue Méd. de Normand., 25 Dec. 1903. Ref. Bulletin de l'Inst. Pasteur, vol. II. p. 552.

PARK, W. H. (1901), Journ. of Hygiene, vol. I. p. 391.

Savage, W. G. (1906), Ibid. vol. vi. p. 123.

Severin, S. and Budinoff, L. (1905), Centralbl. f. Bakteriol., Abt. II. Bd. xiv. p. 463.

Severin, S. (1905), Ibid. p. 605.

Willem and Miede (30 vi. 1905), Revue Génerale du Lait, p. 409. Ref. Bull. de l'Inst. Pasteur, vol. III. p. 725. 